\title{
The Malaysian Fund Managers Perspective on the Viability of Takaful Operators Investment
}

\author{
Amirul Afif Muhamat ${ }^{1 *}$, Mohamad Nizam Jaafar ${ }^{2}$, Norzitah Abdul Karim³, Azreen \\ Roslan $^{4}$, Mohd Faizal Basri ${ }^{5}$ \\ 1,3,4 Department of Economics \& Financial Studies, Faculty of Business \& Management, \\ Universiti Teknologi MARA, Selangor, Malaysia \\ ${ }^{2}$ Arshad Ayub Graduate Business School (AAGBS), UniversitiTeknologi MARA, \\ Selangor, Malaysia \\ ${ }^{5}$ Faculty of Economics \& Management, Universiti Pendidikan Sultan Idris, Perak, \\ Malaysia
}

\begin{abstract}
Takaful operators are expected by the policyholders to act beyond the role of traditional insurance companies that only offer Shariah-compliant protection services. They are expected to be commercially viable. One of the ways to be commercially viable is takaful operators must be able to invest the policyholders' funds in the profitable investment avenues. Nevertheless, the critical issue before investing the funds is to develop products that are suitable with the takaful operators' investment strategy. This study employed a questionnaire survey to gather the feedback of fund managers from 11 takaful operators in Malaysia - all were the senior staffs of takaful operators in Malaysia were surveyed. The questionnaire is developed in the form of a Likert scale ranging from 1 to 5 as the research instrument. By Delphi technique, the draft of the questionnaire was sent to a panel of experts for review, was adopted, and their feedback reflected in the final questionnaire. The experts were a shariah advisor, a corporate finance manager, and a senior executive at the central bank. Findings indicate that policyholders' expectations on their investments are met and the products so far compatible with takaful operators' investment strategies.
\end{abstract}

Keywords: Islamic insurance; Takaful; Islamic finance; Insurance; Investment; Insurance products.

Paper type: Research paper

*Corresponding author: amirulafif@ uitm.edu.my

Received: April 03, 2020; Accepted: May 21, 2020; Published: July 01, 2020

Cite this document: Muhamat, A. A., Jaafar, M. N., Karim, N. A., Roslan, A., Basri, M. F. (2020). The Malaysian Fund Managers Perspective on the Viability of Takaful Operators Investment. Al-Uqud: Journal of Islamic Economics, 4(2), 250-267. doi: http://dx.doi.org/10.26740/al-uqud.v4n2.p250-267

Copyright $@$ 2020 , Al-Uqud: Journal of Islamic Economics http://journal.unesa.ac.id/index.php/jie 
Amirul Afif Muhamat, Mohamad Nizam Jaafar, Norzitah Abdul Karim,

Azreen Roslan, Mohd Faizal Basri: The Malaysian Fund Managers Perspective on the Viability of Takaful Operators Investment

\begin{abstract}
Abstrak: Operator takaful diharapkan oleh pemegang polis untuk bertindak di luar peran perusahaan asuransi tradisional yang hanya menawarkan layanan perlindungan yang sesuai dengan Syariah. Mereka diharapkan menjadi layak secara komersial. Salah satu cara untuk menjadi layak secara komersial adalah operator takaful harus dapat menginvestasikan dana pemegang polis dalam jalan investasi yang menguntungkan. Namun demikian, masalah kritis sebelum menginvestasikan dana adalah untuk mengembangkan produk yang sesuai dengan strategi investasi operator takaful. Penelitian ini menggunakan survei kuesioner untuk mengumpulkan umpan balik dari manajer dana dari 11 operator takaful di Malaysia. Kuesioner dikembangkan dalam bentuk skala Likert mulai dari 1 hingga 5 sebagai instrumen penelitian. Dengan teknik Delphi, rancangan kuesioner dikirim ke panel ahli untuk ditinjau, diadopsi, dan umpan balik mereka tercermin dalam kuesioner akhir. Para ahli adalah penasihat syariah, manajer keuangan perusahaan, dan eksekutif senior di bank sentral. Temuan menunjukkan bahwa harapan pemegang polis atas investasi mereka terpenuhi dan produk sejauh ini kompatibel dengan strategi investasi operator takaful.
\end{abstract}

Kata kunci: Asuransi syariah; Takaful; Keuangan Islam; Pertanggungan; Investasi; Produk asuransi.

\title{
INTRODUCTION
}

Until 2018, there are three types of takaful have been licenced to operate in Malaysia: family takaful; general takaful; and composite takaful (both combined). ${ }^{1}$ Importantly, licences for these takaful operators, issued by the central bank, differ depending on the nature of the takaful business. Islamic Financial Services Act 2013 (IFSA), (2013) mandated significant changes to takaful operations, as it requires a dedicated takaful operator for each type of takaful business. Beginning of 2018 sees the end of the five-year transition period provided under IFSA 2013 for composite takaful companies to implement the requirement to separate their family and general takaful businesses into two separate entities. To date (as of March 2018), only one composite takaful operator, Etiqa Takaful Berhad, has officially segregated the entity into general takaful and family takaful businesses. This operator is also evidenced in the appointment of separate chief executive officers for each of the two businesses - Etiqa General Takaful and Etiqa Family Takaful. The remaining composite takaful operators are expected to follow soon, since $1^{\text {st }}$ July 2018 is the cut-off date for completion of the business segregation process.

A consequence of IFSA, (2013) is the expected change in the number of Malaysia's takaful operators to be more than the 11 companies that existed as of the time of its announcement. ${ }^{2}$ Potential changes may result from mergers between general takaful businesses, shifts in ownership due to the changing of

\footnotetext{
${ }^{1}$ The composite takaful operators are Syarikat Takaful Malaysia Berhad, Takaful IkhlasBerhad, Etiqa Takaful Berhad, Sun Life Takaful Berhad, HSBC Amanah Takaful Berhad, Hong Leong MSIG Takaful Berhad and MAA Takaful Berhad. The remaining four takaful operators focus on family takaful business only: Prudential BSN Takaful Berhad; Great Eastern Takaful Berhad; AIA Takaful Berhad; and AmFamily Takaful Berhad.

${ }^{2}$ After 2010, there were 12 takaful operators. However, early in the fourth quarter of 2012, AIA AFG TakafulBerhad merged with ING Public Takaful Ehsan Berhad. This merger was a result of the parent companies' activities, whereby AIA Group Ltd bought the ING Groep NV business in Malaysia. Thus, the number of takaful operators was reduced to 11 companies.
} 
stakes in these general takaful businesses, or the winding up of companies after transferring the remaining cases or policies to other takaful operators (Singh, 2013). Nevertheless, evidence from the split of Etiqa Takaful Berhad into Etiqa Family Takaful and Etiqa General Takaful, suggests that operational changes may be minimal, at least in the short term. This split reflects that most business functions are still shared, as in the previous entity. These include areas such as customer service, human resources, and the agency platform. Although the transition is still ongoing, the only noticeable operational change has been the appointment as mentioned earlier of separate CEOs for each of the two takaful businesses.

The introduction of Risk-Based Capital for Takaful operators (RBCT) is also expected to shape trends in terms of the number of operators. Under the Takaful Act 1984, the central bank had previously specified a minimum capital of MYR 100 million for takaful operators. However, under IFSA 2013 minimum capital requirements are subject to the central bank's discretion, there being no specification on such a threshold as per the previous Act (Kassim \& Ismail, 2014). This suggests takaful operators might be established with smaller capital requirements, enabling new industry entrants to be driven more by the nature and complexity of the type of takaful business chosen (Htay et al., 2015).

As well as changing the competitive environment, an important consequence of IFSA, (2013) implementation is its potential impact on investment strategy (and profitability) — the focus of this paper. Takaful operators' investment strategies (and profits) are closely related to the products offered, each of which embeds specific investment objectives (Mohamad et al., 2019). Both the takaful products made available, and fund participants' demand for these products will influence takaful operators' investment practices (Ali et al., 2019). This article highlights the importance of takaful products to investment practice and presents findings derived from feedback to a questionnaire provided to each of Malaysia's 11 takaful operators' fund managers. This research focus is regarding the availability of takaful products to meet their investment needs. The findings, therefore, reflect the industry's perspective on this issue.

The rest of the paper is presented as follows. Section 2 discusses the types of takaful product available and the features of each. Section 3 provides a brief outline of the research method. Section 4 presents the findings from the questionnaire. Section 5 finishes the paper, providing conclusions and suggestions for future research.

\section{Takaful Products}

The takaful industry in Malaysia is regarded as 'takaful-tijari' or 'commercially driven', asseen in the structure and business model of every takaful operator in Malaysia (Bank Negara Malaysia, 2004).

This model is either in the form of a modified wakalah or hybrid wakalah (Olorogun, 2015). Takaful operators in Malaysia commonly derive their earnings from wakalah (agency) fees, the surplus from the participant special account (PSA), and fees or profit-sharing from the investment of the participant account (PA) (Alkhan \& Hassan, 2020). The earnings trend for takaful operators evidence 
that investment profit has gradually become the most important source of income, slowly surpassing the wakalah fee (Kantakji et al., 2020). This is a good sign for the companies as well as fund participants because it demonstrates that takaful operators are actively seeking investments and portfolios to maintain and improve the investment returns that support the products their businesses offer (Muhamat et al., 2019). Moreover, the type of takaful model adopted, such as waqf model or others (Zakaria et al., 2019); might influence the investment management of the firms.

In general, takaful products can be placed into three categories:

General takaful (Islamic general insurance) offers protection or coverage against risks of a general nature for companies or individuals (takaful contributors). General takaful products include motor insurance, fire and allied perils, workers' compensation, marine cargo, engineering insurance, property and transport (Echchabi \& Ayedh, 2015; Hassan et al., 2018). Investment returns are used to smooth the takaful premium (contribution) cost since general takaful is mostly comprised of short-term contractual policies. As such, a positive investment return will help to keep the premium cost lower.

Family takaful (Islamic life insurance) provides coverage for participation by individuals or corporate bodies on a long-term basis with maturity periods that generally range from 10 to 40 years. Family takaful products include medical and health plans, education, accident, marriage, hajj and umra plans, lump-sum investments, savings plans, retirement plans, and mortgages (Salleh \&Laksana, 2018; Remli \& Rosman, 2018). Investment returns are the source of wealth accumulation since family takaful involves long-term contractual policies. Takaful contributors expect to build up wealth (saving) as well as receiving protection. ${ }^{3}$

Retakaful coverage (Islamic reinsurance) offers coverage for takaful companies against risks, including loss or dilution of capital and reserves resulting from high claim exposures.

From takaful contributors' perspectives, utilising general and family takaful products is of interest, retakaful being intended only for takaful operators. Furthermore, the above-listed takaful products can be broadly classified as savings or risk-coverage products (Odierno, 2012). In practice, many takaful operators'products combine both savings and coverage features, although the feature that dominates varies according to each product's primary objective.

For instance, an investment-linked policy (ILP) is usually bundled with protection. However, a large portion of the premium (contribution) is channelled to investment, and only a minor part is pooled into the risk fund.

\footnotetext{
${ }^{3}$ As Odierno (2012) explains, the return is not guaranteed for takaful savings products. Nevertheless, for marketing purposes, takaful operators can build up contributors' expectations by constructing an implicit guarantee based on the invested assets, by holding stable rather than volatile assets.
} 
Table 1: Family Takaful: Distribution of New Business Contributions by Plan

\begin{tabular}{cccccc}
\hline \multicolumn{5}{c}{ Family Takaful Products (MYR million) } \\
\hline Year & $\begin{array}{c}\text { Ordinary } \\
\text { Family }\end{array}$ & Temporary & Others & $\begin{array}{c}\text { Investment } \\
\text {-Linked }\end{array}$ & Total \\
\hline 2009 & $1,582.5$ & 3.4 & 454 & 880.9 & $2,920.8$ \\
2010 & $1,798.9$ & 5.9 & 498.3 & $1,179.2$ & $3,482.2$ \\
2011 & $1,951.7$ & 56.1 & 550.3 & $1,515.4$ & $4,073.5$ \\
2012 & $1,827.5$ & 128.7 & 533.6 & $2,061.3$ & $4,551.1$ \\
2013 & $1,891.1$ & 196.1 & 580.6 & $2,495.5$ & $5,163.3$ \\
2014 & $1,885.7$ & 325.9 & 623.8 & $3,087.9$ & $5,923.3$ \\
2015 & $1,956.9$ & 114.8 & 643.7 & $3,819.5$ & $6,534.9$ \\
\hline
\end{tabular}

Source: Central Bank of Malaysia. Figures are adjusted to the nearest decimal Note: \# MYR = Malaysian Ringgit

The endowment policy has a contractual period for a specified number of years, whereby compensation will be given when death occurs, or when the policy reaches maturity. This policy acts as a saving instrument and at the same time, protects the takaful contributors (Lewis \& Wallace, 1997). An example is an endowment policy for education with life coverage.

Temporary policy refers to a policy with a specified number of years to maturation, with a constant annual premium (contribution) being determined. At the end of the contractual period, takaful contributors will have the option to renew the policy. An example of a temporary policy is a mortgage or MRTT (mortgage reducing term takaful), where the takaful operator will help to settle the house financing of takaful contributors in the case of death and permanent disability. In Malaysia, this plan tends to involve a single paid premium (contribution) which means that the takaful operator will hold prepaid premium monies on behalf of the contributors for as long as 15 to 20 years (Muhamat et al., 2017). As such, proper investment of the fund is needed (Odierno, 2012).

Another takaful plan is the medical and health policy. This plan will assist with contributors' medical needs in the form of financial assistance for surgery and hospitalisation, which normally requires a substantial amount of money (Wahab \& Tajuddin, 2020). In terms of duration, Odierno (2012) states that this policy can be as long as a MRTT. Nevertheless, in terms of premiums paid, the medical and health takaful plan is based on regular contributions compared to MRTT, which is normally in a lump-sum payment. The early paid premiums in this plan will be used to offset future risk related to the age-risk factor by building-up the fund through investment. This plan can also be sold in rider form attached to a unit-linked or traditional savings plan (Parveen et al., 2019).

A takaful annuity is a kind of policy intended to assist the takaful contributor upon retirement until death by supplying a fixed amount of income every year. Annuities were sold for a short period in the early 2000s in Malaysia (Odierno,2012) before the demand for the product was affected by the withdrawal of the Employees Provident Fund of Malaysia (EPF) from the annuity scheme. The plan was structured in two portions, an accumulation period and a payout period. Both periods were generally of long duration. Odierno (2012) signifies 
that the plan does not guarantee a return, but because of promotion, it is viewed as implicitly guaranteed and treated as such by the regulators.

The investment-linked policy (ILP) function as a savings instrument and at the same time provides minimum compensation to takaful contributors in case of death. The saving or investment portion in the Participant Account (PA) is unitised into units linked to investment portfolios similar to unit trust investments (Adawiah et al., 2008). A large portion of the premiums paid (some allocation is also made for an administration fee and protection benefits) will be used to buy investment-linked units, such as a unit trust or other form of investment determined by the takaful operator.

The ILP adopts a 'drip' basis, ${ }^{4}$ Whereby some amount of funds is gradually transferred from the Participant Account (savings fund) to a Participant Special Account (risk fund) (Odierno, 2012). The premium (contribution) is paid regularly. If there is no claim from the policyholder in that particular year, the person is entitled to receive a return, which will be used to buy additional investment-linked units (Noor, 2009). The contributors' funds are directly linked to the value of the assets in which the funds are invested. The proceeds depend upon the growth in interim performance of the underlying fund or investment pool, with the remaining units being sold at maturity, or in the case of the death of the takaful contributors (Lewis, 2005).

\section{General Takaful Products}

General takaful products are viewed as short-term plans, excepting some longtailed policies. Even so, general takaful's long-tailed policies are periodically shorter than family takaful products (Odierno, 2012). Longtails on policies result from long settlement times in the case of legal procedures caused by lawsuits involving clients in third-party motor, workman's compensation, and third-party liability cases. The contribution (premium) for general takaful usually is based on yearly contributions and is renewable at the end of the period.

\section{Takaful Product's Influence on Investment}

The distinguishing feature of takaful operators who embrace the stock form of takaful model (Naim et al., 2020), is that the takaful contributors bear investment costs to each product; either investment-linked products or others (e.g. endowment, mortgage, medical and health). Investment costs are charged through an investment fee paid to takaful operators, or via a nominated cost against contributions paid by takaful contributors and separated between the participant special account (PSA) and the participant account (PA). For every takaful product, the premium (contribution) paid will be segregated into a dedicated investment account, which will be invested in a variety of investment instruments (Soualhi \& Al Shammari, 2015).

It is also important to note that for investment-linked products, the central bank has specified a ceiling price as a guideline for takaful operators when developing and selling their investment-linked products. However, for other

${ }^{4}$ Contributions (premiums) will be deducted for the wakalah (agency) fee in advance, before being invested into the PA fund. Gradually, a sum of money will be transferred to the PSA to build-up the risk fund for compensation benefits. 
products, the investment fee is at the discretion of the takaful operator (Bank Negara Malaysia, 2013).

That the forms of insurance product offered by a firm have a significant influence on its required investment strategy is clear (Shahid, 2020). For example, where investment guarantees are offered as part of a product, policyholders cover the costs of providing these guarantees, with the insurer investing funds raised from these charges on risk management - hedging, or additional equity capital, or reinsurance (e.g., see Huber et al., 2015). Additionally, product innovation (e.g., the addition of an investment or savings vehicle to a life insurance product) will require modification of the businesses' investment strategy (Carino et al., 1994). Thus, the set of takaful products it offers will influence the takaful operator's investment needs (Tolefat, 2009), reflecting the cash flow profiles that it must manage (Kantakji et al., 2020).

For family takaful, the endowment policy requires the operator to manage an accumulated balance of takaful contributors' savings (Alotaibi \& Hariri, 2020). For annuities, insurers (takaful operators) have to manage a de-cumulating balance of the contributors' savings (Lewis \& Wallace, 1997). For the investmentlinked policy, takaful operators have to be prudent in managing a stream of income (premium) that will be used to buy additional investment units (Alshammari et al., 2018).

These products carry with them inherent risks or forecast liabilities that are long-term. Thus, each is likely to require the need to make use of longer-dated investments and must offset risks with investment instruments that provide stable returns and less volatility.

In contrast, in general takaful, most risks are short-term. Additionally, the short-tailed nature of most general takaful products suggests lower requirements for both income and term from takaful investment. As such, the appropriate investment instruments would be those that earn a modest income and at the same time possess liquidity. Nevertheless, as mentioned earlier, some 'long-tailed' policies (e.g., workers' compensation claims), having medium-term risks, may require a suitable investment strategy in order to meet future requirements of the policy, such as those deriving from litigation procedures. For example, in Saudi Arabia, the general takaful business is more significant than family takaful, which differs from the situation in Malaysia and Indonesia (Ismail et al., 2017).

However, despite the lower investment profit required by general as compared to family takaful, positive investment performance is still needed to lower the future premium (contribution) costs for takaful contributors. This positive performance is essential in order to keep current takaful contributors with the takaful operator, and also as a marketing feature to attract new customers.

\section{Takaful Operators' Investment Profits}

Takaful operators have earned significant income from their companies' investment activities over the years. Investment profit (at the gross income level) displays a definite upward trend for all takaful operators, including the industry "newbies", even if they are yet to record any net profit since inception. 
This reflects two important points discussed in the previous section: investment earnings are tagged to the products offered (due to the products' features); and concentration or focus on selling certain types of takaful products will influence the trend in investment profit (Rahmanto et al., 2020). Table 2 reports the investment profits for each takaful operator in Malaysia, segregated into the family or general takaful business, as per the companies' annual reports for the last five years.

Table 2: Investment profits for takaful operators in Malaysia (2012-2016)

\begin{tabular}{|c|c|c|c|c|c|c|c|c|c|c|c|}
\hline \multirow{2}{*}{ No. } & \multirow{2}{*}{ Takaful Operators } & \multicolumn{5}{|c|}{$\begin{array}{c}\text { General Takaful } \\
\text { (MYR'000) }\end{array}$} & \multicolumn{5}{|c|}{$\begin{array}{c}\text { Family Takaful } \\
\text { (MYR'000) }\end{array}$} \\
\hline & & $\begin{array}{l}\text { Year } \\
2012\end{array}$ & $\begin{array}{l}\text { Year } \\
2013\end{array}$ & $\begin{array}{l}\text { Year } \\
2014\end{array}$ & $\begin{array}{l}\text { Year } \\
2015\end{array}$ & $\begin{array}{l}\text { Year } \\
2016\end{array}$ & $\begin{array}{l}\text { Year } \\
2012\end{array}$ & $\begin{array}{l}\text { Year } \\
2013\end{array}$ & $\begin{array}{l}\text { Year } \\
2014\end{array}$ & $\begin{array}{l}\text { Year } \\
2015\end{array}$ & $\begin{array}{l}\text { Year } \\
2016\end{array}$ \\
\hline \multirow[t]{2}{*}{1.} & Syarikat & & & & & & & & & & \\
\hline & Malaysia Bhd & $\bar{m}$ & î & $\frac{\pi}{2}$ & $\begin{array}{l}\overline{8} \\
\text { बे }\end{array}$ & $\begin{array}{l}\text { गे } \\
\text { शे }\end{array}$ & $\begin{array}{l}\infty \\
\overbrace{0} \\
\infty \\
\infty\end{array}$ & 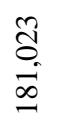 & $\frac{\wp}{2}$ & $\begin{array}{l}\stackrel{2}{N} \\
\ddot{n} \\
\ddot{\sim}\end{array}$ & 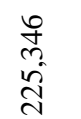 \\
\hline
\end{tabular}

2. TakafullkhlasSdnBhd

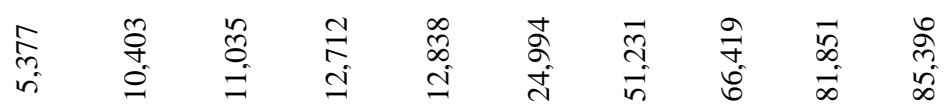

3. Prudential BSN

TakafulBhd

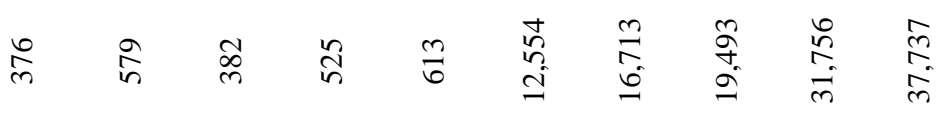

4. Hong Leong MSIG TakafulBhd

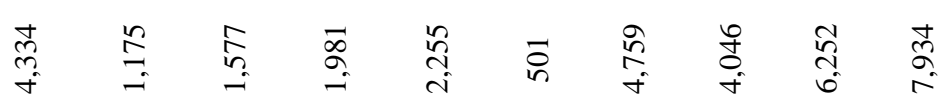

5. HSBC AmanahTakaful (Malaysia) Bhd

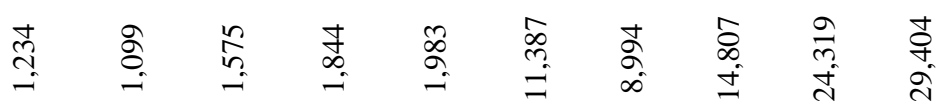

6. Great Eastern TakafulSdnBhd

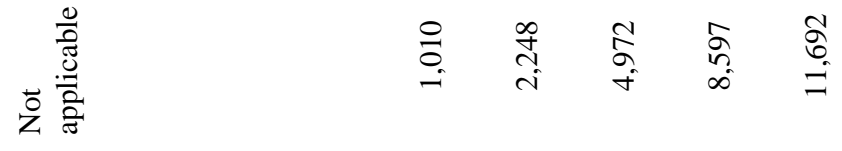

7. EtiqaTakafulBhd

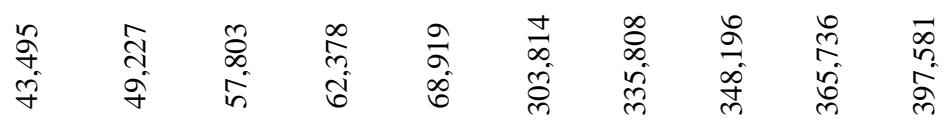

8. Sun Life Malaysia TakafulBhd

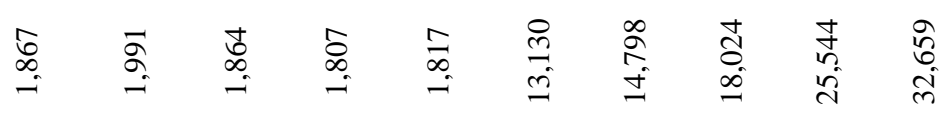


9. AmMetLifeTakafulBhd

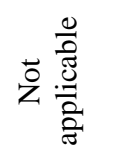

10. AIA Public

TakafulBhd

$z \frac{\frac{0}{0}}{\frac{0}{\tilde{c}}}$

11. Zurich Takaful

Malaysia Bhd ${ }^{6}$

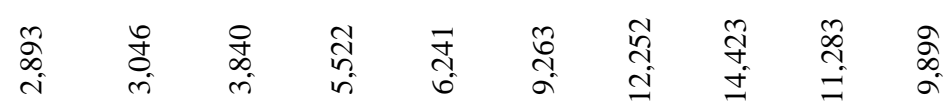

\section{RESEARCH METHODS}

This study employed a questionnaire with a Likert scale ranging from 1 to 5 as the research instrument. The Delphi technique, in which the draft of the questionnaire was sent to a panel of experts for review, was adopted and their feedback reflected in the final questionnaire. The experts were a shariah advisor, a corporate finance manager, and a senior executive at the central bank. Questionnaires were distributed to the fund managers of the 11 takaful operators in Malaysia meaning that senior staffs in all takaful operators in Malaysia were surveyed.

Five statements were developed to explore takaful products (TP) in the context of takaful operators' investment practices. These statements were designed to investigate the influence of takaful products from several perspectives: takaful operators' investment strategies; the availability of financial market instruments to support the strategies; the targeted market segment; and the expectation of investment-linked takaful products being prioritised by takaful operators (only in the family takaful business).

The statements are as follows:

1) Our firm's investment style is influenced by the products offered by the takaful operator.

2) The takaful operator lacks products to serve its investment objectives.

3) There are sufficient capital market instruments to match the investment objectives related to takaful products.

4) At present, takaful products are directed to selected market segments.

5) The company always meets takaful contributors' expectations on investment returns as promoted by the investment-linked takaful products.

Responses were recorded on the Likert scale between 1 (strongly disagree) and 5 (strongly agree), with a score of 3 indicating the participant was undecided on the statement.The respondents' feedback was then analysed using descriptive

\footnotetext{
${ }^{5}$ Combination of investment income from two takaful operators due to acquisition (AIA Public Takaful \& ING Takaful Ehsan Bhd).

${ }^{6}$ Zurich Insurance Company Ltd acquired MAA Takaful Bhd in 2015; established Zurich Takaful Bhd.
} 
analysis, followed by the use of Mann-Whitney U tests (a non-parametric test) to assess differences between responses from general and family takaful businesses.

A non-parametric test is used due to the use of an ordinal scale for most of the questionnaire's items (Burns \& Burns, 2008). Additionally, although the industry population (takaful operators) was surveyed, the study's small sample size (11 takaful operators) and focus on the in-house fund managers of takaful operators, each suggests that normality assumptions cannot be met. As such, nonparametric tests are appropriate assessment tools for the analyses, as they make fewer and less stringent assumptions compared to parametric tests (Burns \& Burns, 2008; Collis \& Hussey, 2009).

\section{RESULTS AND DISCUSSION}

In the following, a descriptive presentation and a brief discussion of the survey findings are followed by the presentation and discussion of the results of nonparametric tests.

\section{Descriptive analysis}

Questionnaire statement: The products offered by the takaful operator influences our firm's investment style.

$91.3 \%$ or 21 respondents in family takaful agreed with the statement while only $8.7 \%$ or two respondents disagreed (Table 3 ). The same pattern was shown in general takaful, with $94.1 \%$ or 16 respondents agreeing with the statement while $5.9 \%$, equivalent to one respondent, disagreed. The near-consensus results correspond with those of Tolefat\& Asutay (2013) and In Lewis \& Wallace (1997) study about the influence of takaful and insurance products on the institution's investment style, the investment strategies of takaful operators are closely related to the type of products offered by the takaful operators, which requires 'a mix and match approach' in terms of assets and liabilities (Khan, 2007). In the context of family takaful, the emphasis is placed more on long- and medium-term investment objectives, while for general takaful operators, their consideration is more on short-term investment requirements.

Table 3: The products offered by takaful operator influences our firm's investment style

\begin{tabular}{llrr}
\hline Investment Funds & Responses & Frequency & Per cent \\
\hline Family Takaful & Strongly Agree & 4 & 17.4 \\
& Agree & 17 & 73.9 \\
& Disagree & 2 & 8.7 \\
& Total & 23 & 100.0 \\
General Takaful & Strongly Agree & 4 & 23.5 \\
& Agree & 12 & 70.6 \\
& Disagree & 1 & 5.9 \\
\cline { 2 - 4 } & Total & $\mathbf{1 7}$ & $\mathbf{1 0 0 . 0}$ \\
\hline
\end{tabular}


Questionnaire statement: The takaful operator lacks products to serve its investment objectives.

Table 4: The takaful operator lack products to serve its investment objectives

\begin{tabular}{llrr}
\hline Investment Funds & \multicolumn{1}{c}{ Responses } & Frequency & Per cent \\
\hline Family Takaful & Agree & 9 & 39.1 \\
& Undecided & 1 & 4.3 \\
& Disagree & 11 & 47.8 \\
& Strongly Disagree & 2 & 8.7 \\
& Total & 23 & 100.0 \\
General Takaful & Agree & 7 & 41.2 \\
& Undecided & 1 & 5.9 \\
& Disagree & 7 & 41.2 \\
& Strongly Disagree & 2 & 11.8 \\
\cline { 2 - 4 } & Total & $\mathbf{1 7}$ & $\mathbf{1 0 0 . 0}$ \\
\hline
\end{tabular}

A similar level of concordance to that in Table 3 is displayed in Table 4 for both kinds of takaful business. However, in this case, most respondents disagreed with the statement. Variation in the responses indicates that, for some fund managers, achieving the investment objectives prescribed by their companies is challenging. Despite the small difference, $39.1 \%$ respondents in family takaful and $41.2 \%$ respondents in general takaful felt that their companies lacked the set of takaful products to best suit their investment objectives.

More than half of the respondents in each business: $56.5 \%$ or 13 respondents in family takaful and 53\% or nine respondents in general takaful rejected the questionnaire statement. This implies that a small majority of them felt that takaful operators have sufficient products in the market to suit their investment objectives. In both businesses, only one respondent felt neutral towards the statement.

As mentioned earlier, this statement complements the earlier ones. Responses to the statement are summarised in Table 3 and identify the potential influence of takaful products on the firms' investment style. Table 4 surveys opinions as to whether the takaful products are sufficient to support the firms' investment objectives. The top-down approach (as verified by one of the takaful operator's CIOs) of developing the investment objectives before designing the takaful products signifies that takaful operators should have sufficient products to cater to their investment needs and clients' demands because each investment objective is tagged with a range of products. This concurs with the findings of (Khan, 2007).

Nevertheless, a requirement to continuously be innovative is deemed necessary since products are currently too focused on selected market segments. This suggests that there are untapped business opportunities to be explored. For example, green takaful products are yet to be explored by takaful operators globally. 


\section{Questionnaire statement: There are sufficient capital market instruments to} match the investment objectives related to takaful products.

The results for this statement indicate mixed of respondents' opinions in both businesses; yet, the pattern is similar, as shown in Table 5. For family takaful, $47.8 \%$ or 11 respondents supported the statement while $34.8 \%$ or eight respondents opposed it, and four respondents or $17.4 \%$ remained neutral. General takaful operators were more evenly split in their opinions since $41.2 \%$ or seven respondents supported and rejected the statement, while $17.6 \%$ or three respondents remained neutral.

Table 5: There are sufficient capital market instruments to match the investment objectives related to takaful products

\begin{tabular}{clrr}
\hline Investment Funds & Responses & Frequency & Per cent \\
\hline Family Takaful & Strongly Agree & 2 & 8.7 \\
& Agree & 9 & 39.1 \\
& Undecided & 4 & 17.4 \\
& Disagree & 8 & 34.8 \\
& Total & 23 & 100.0 \\
General Takaful & Strongly Agree & 2 & 11.8 \\
& Agree & 5 & 29.4 \\
& Undecided & 3 & 17.6 \\
& Disagree & 7 & 41.2 \\
\cline { 2 - 4 } & Total & $\mathbf{1 7}$ & $\mathbf{1 0 0 . 0}$ \\
\hline
\end{tabular}

The availability of capital market instruments to accommodate the demands of financial institutions, including takaful operators, is imperative due to the scarcity of such instruments for the niche Islamic finance sector. Nevertheless, Malaysia has a comprehensive Islamic financial system, supported by four main components: an Islamic banking sector, the takaful sector, an Islamic money market, and an Islamic capital market. These four components complement each other in such a way that the financial products of each sector are utilised to meet the financial needs of the institutions.

For instance, a takaful operator may manage its long- - and medium-term investment horizons by investing in Sukuk or Islamic bonds, and sometimes on properties in the form of either physical real estate or Islamic real estate investment trusts, i-REITs (Khan, 2007; Tolefat \& Asutay, 2013). On the other hand, for short-term investment requirements, funds will be heavily invested in the Islamic money market via funds deposited in the Islamic banks in the form of special investment accounts (Khan, 2007).

The Islamic financial instruments in Malaysia may be considered as adequate. However, competition from other Islamic financial institutions, combined with the demands from conventional financial institutions for the same instruments, may cause some disruptions to the takaful operator when it comes to the 'mix and match' process for the investment portfolio. Accordingly, some may perceive the capital market instruments as inadequate to cater for the takaful operators' needs. 
Questionnaire statement: At present, takaful products are directed to selected market segments.

Table 6 depicts that in family takaful, a majority of the respondents concurred with the statement, $60.9 \%$ or 13 respondents, whereas $30.4 \%$ or seven respondents objected to it. Also, two respondents (8.7\%) remained undecided. In generaltakaful, a similar trend is evident as a majority of the respondents supported the statement, $64.7 \%$ or 11 respondents, while $29.4 \%$ rejected it, and one respondent $(5.9 \%)$ chose to be neutral.

Table 6: At present, takaful products are directed to selected market segments

\begin{tabular}{llrr}
\hline Investment Funds & Responses & Frequency & Per cent \\
\hline Family Takaful & Strongly Agree & 1 & 4.3 \\
& Agree & 13 & 56.5 \\
& Undecided & 2 & 8.7 \\
& Disagree & 7 & 30.4 \\
& Total & 23 & 100.0 \\
General Takaful & Strongly Agree & 1 & 5.9 \\
& Agree & 10 & 58.8 \\
& Undecided & 1 & 5.9 \\
& Disagree & 5 & 29.4 \\
\cline { 2 - 4 } & Total & $\mathbf{1 7}$ & $\mathbf{1 0 0 . 0}$ \\
\hline
\end{tabular}

A majority of the respondents in both business areas were of the view that, to some extent, takaful operators are selective in selling their takaful products. This is due to the higher income being generated from such products in the form of wakalah(agency) fees.In family takaful, product concentration can be seen in personal takaful coverage, whereas in general takaful it would be on vehicle takaful coverage. For family takaful, this situation is not a deliberate plan of the takaful operators. Instead, it may be caused by the heavy use of agents in family takaful businesses. The agents would be remunerated in the form of commissions from takaful operators for every successful case.

On the other hand, road traffic regulations require automobile owners to buy car insurance, at least third-party coverage. This has successfully contributed to the high numbers of policies or takaful certificates sold for automobile takaful policy - a general takaful product.

Questionnaire statement: The company always meets takaful contributors' expectations on investment returns as promoted by the investment-linked takaful products.

The statement for Table 7 is only valid for family takaful businesses, as it deals with the investment-linked products offered by every family takaful operator in Malaysia. A majority of the respondents, $78.3 \%$ or 18 respondents, supported the statement while $21.7 \%$ or five respondents remained neutral, and none rejected it. As discussed in Section 2, investment-linked takaful products are the most significant income source for the takaful operators. These serve as protection and savings vehicles at the same time. As a result, it is essential to determine the 
takaful operators' capacity to meet the investment returns promoted by their agents and stated in their marketing pamphlets.

On the other hand, takaful operators are more than capable of managing the other function of protection coverage. The responses received show that most feel their companies have fulfilled their assurances by delivering investment returns as marketed. ${ }^{7}$

Table 7: The company always meets takaful contributors' expectations on investment returns as promoted by the investment-linked takaful products

\begin{tabular}{llrr}
\hline Investment Funds & Responses & Frequency & Percent \\
\hline Family Takaful & Strongly Agree & 1 & 4.3 \\
& Agree & 17 & 73.9 \\
& Undecided & 5 & 21.7 \\
\cline { 2 - 4 } & Total & $\mathbf{2 3}$ & $\mathbf{1 0 0 . 0}$ \\
\hline
\end{tabular}

\section{Non-parametric test (Mann-Whitney U Test)}

The Mann-Whitney (MW) test is used to establish the difference between two independent samples. It bears a resemblance to the t-test in the parametric analysis. Takaful funds are characterised by their business objective: either family or general takaful. Therefore, these types of funds were tested with other items in the questionnaire in order to determine if there are significant differences between the sector's two types of takaful funds.

The results indicate that both groups of respondents (funds managers of family and general takaful) gave similar and comparable answers to each question. This signifies that investment practices in general takaful and family takaful are similar. This can be traced to the companies' structures, as presented earlier; some takaful operators are composite takaful operators, which mean that they manage both products. This situation might be different in the future when composite takaful operators have separated into two separate business entities.

Fund managers' feedback to the questionnaire that forms the basis for this study signifies that the set of takaful products offered is suited to be matched by their companies' investment strategies, as well as fulfilling expectations of policyholders.

Table 9: Mann-Whitney U Test: Line of Business or Takaful Products (between family and general takaful funds)

\begin{tabular}{lc}
\hline \multicolumn{1}{c}{ Items } & Line of Business (excl. item on investment-linked) \\
\hline Mann-Whitney U & 185.00 \\
Asymp. Sig (2 tailed) & .771 \\
Note & No significant difference \\
\hline
\end{tabular}

${ }^{7}$ To verify this,a survey of takaful contributors on their investment returns would be required. However, that is not this study's aim, suggesting consideration as a project for future study. Nevertheless, this statement can also be verified with published secondary data in the form of takaful operators' fact sheets. 


\section{CONCLUSION}

In a nutshell, this study informs that the takaful products' return requirements will influence the investment strategy for takaful operators' investment funds. Therefore, takaful operators need to develop new products that can meet the customers' demands, as well as being capable of matching the expected return marketed in the takaful policy. At the present moment, the policyholders (participants) are satisfied with the current products and the returns that they received. However, continuous improvements must become the agenda of takaful operators to ensure the relevancy of the products and sustainability of the returns.

This study has been constrained by a lack of data re actual takaful policies (products) sold by the takaful operators (due to commercial sensitivity of the data). Such data would enable readers to decipher critical information, especially on the concentration of products focused on or emphasised by takaful operators. Nevertheless, this issue is mitigated through the use of the respondents' questionnaire feedback on the takaful policies sold by their companies.

For future research, a replication of this study may be executed in other country or region, to determine whether similar traits exist amongst takaful operators, and also to account for differences between different populations' needs and demands. This will contribute to further understanding of takaful operators' investment practices and their relationship to the set of investment products offered.

\section{ACKNOWLEDGEMENTS}

We would like to express our gratitude to the Faculty of Busines and Management for the research grant offered (600-IRMI 5/3/DDF(FPP) 006/2019).

\section{REFERENCES}

Adawiah, E. R., Odierno, H. S.,\& Ismail, A.(2008).Essential guide to takaful (Islamic Insurance). CERT Publications Sdn. Bhd.

Ali, M., Raza, S. A., Puah, C. H., \& Amin, H. (2019). Consumer acceptance toward takaful in Pakistan: An application of diffusion of innovation theory. International Journal of Emerging Markets, 14(4). https://doi.org/10.1108/IJOEM-08-2017-0275.

Alkhan, A. M., \& Hassan, M. K. (2020). Takaful operators: analysing segregated accounts between operator/participants. Journal of Islamic Accounting and Business Research. https://doi.org/10.1108/JIABR-01-2020-0005.

Alotaibi, K. O., \& Hariri, M. M. (2020). Content analysis of Shariah-compliant investment equity funds in KSA: does social justice matter?. International Journal of Business and Management, 15(6). https://doi.org/10.5539/ijbm.v15n6p1.

Alshammari, A. A., Alhabshi, S. M. S. J., \& Saiti, B. (2018). A comparative study of the historical and current development of the GCC insurance and takaful industry. Journal of Islamic Marketing, 9(2).https://doi.org/10.1108/JIMA05-2016-0041. 
Bank Negara Malaysia.(2004).20 Years Experience of Malaysian Takaful Industry.

https://www.bnm.gov.my/files/publication/tkf/en/2004/booklet.en.pdf

Bank Negara Malaysia. (2013).'Life insurance and family takaful framework: concept

paper'.http://www.bnm.gov.my/files/2013/Life_Insurance_and_Family_Tak aful_FrameworkConcept_Paper.pdf $>$.

Burns, R. P.,\& Burns, R.(2008).Business Research Methods and Statistics using SPSS. SAGE.

Carino, D.R., Kent, T., Myers, D.H., Stacy, C., Sylvanus, M., Turner, A.L., Watanabe, K. \& Ziemba, W.T.(1994) The Russell-Yasuda Kasai model: An asset/liability model for a Japanese insurance company using multistage stochastic programming. $\quad$ Interfaces, $24, \quad 29-49$. https://doi.org/10.1287/inte.24.1.29.

Collis, J \& Hussey, R.(2009).Business Research: A Practical Guide for Undergraduate \& Postgraduate Students(3rd ed.). Palgrave Macmillan.

Echchabi, A., \& Ayedh, A. M. (2015). Factors influencing the Yemeni customers' intention to adopt takaful products. Gadjah Mada International Journal of Business, 17(1). https://doi.org/10.22146/gamaijb.25799

Hassan, R., Salman, S. A., Kassim, S., \& Majdi, H. (2018). Awareness and knowledge of takaful in Malaysia: a survey of Malaysian consumers. International Journal of Business and Social Science, 9(11). https://doi.org/10.30845/ijbss.v9n11p6

Htay, S. N. N., Hamat, M., Ismail, W. Z. W. \& Salman, S. A. (2015). Takaful (Islamic insurance): historical, Shari'ah and operational perspectives. International Business Management, 9(1). https://doi.org/10.36478/ibm.2015.65.69

Huber, C., Gatzert, N. \&Schmeiser, H.(2015). How does price presentation influence consumer choice? The case of life insurance products. Journal of Risk and Insurance,82(2), 401-432. https://doi.org/10.1111/jori.12026.

Islamic Financial Services Act 2013 (IFSA 2013)

Ismail, F., Jaffer, S., Unwin, L., Jamil, S., Hassan, A. A. M., Alajaji, K., \& Tan, Y. Y. (2017). Global takaful report 2017: market trends in family and general takaful. http://us.milliman.com/uploadedFiles/insight/2017/Takaful2017-full-report.pdf.

Kantakji, M. H., Hamid, B. A., \& Alhabshi, S. O. (2020). What drives the financial performance of general takaful companies?.Journal of Islamic Accounting and Business Research.https://doi.org/10.1108/JIABR-06-2018$\underline{0077 .}$

Kassim, Z. A. M., \& Ismail, F.(2014). Updates on Takaful: Regulating the way forward. Actuarial Partners. http://www.takaful.coop/images/stories/Updates_on_takaful_Regulating_th e_way_forward_Article_FINAL_12122013.pdf.

Khan, G. Z. (2007). How Takaful Funds can Manage Investment to Optimise Returns. MIR Takaful Investment. 
Lewis, M.,\& Wallace, R. H.(1997).The Australian Financial System: Evolution, Policy and Practice. Addison Wesley Longman.

Lewis, M. K.(2005). 'Wealth creation through takaful (Islamic insurance)', in Iqbal, M \& Wilson, R (eds), Islamic Perspectives on Wealth Creation(pp. 167-187).Edinburgh University Press.

Mohamad, S. F. S., Alhabshi, S. O., \& Lahsasna, A. (2019). Matrix equations in reciprocal cost allocation: an application in the takaful industry in Malaysia. International Journal of Accounting, 4(17), 6675.http://doi.org/10.1016/j.ijinfomgt.2014.10.006.

Muhamat, A. A., Jaafar, M. N., \& Alwi, S. F. S. (2017). General Takaful claims: an experience of takaful operator in Malaysia. Journal of Emerging Economies \& Islamic Research, 5. https://doi.org/10.24191/jeeir.v5i4.8833.

Muhamat, A. A., Jaafar, M. N., \& Saad, M. S. M. (2019). Essential components of takaful Operation. UTeM.

Muhamat, A. A., Jaafar, M. N., Basri, M. F., Alwi, S. F. S., \& Mainal, S. A.(2017). Green takaful as a climate finance tool. Advanced Science Letters, 23(8), 7670-7673. https://doi.org/10.1166/asl.2017.9549.

Naim, A. M., Isa, M. Y., \&Rahim, A. K. A. (2020). The concept of mutual takaful model. Journal of Talent Development and Excellence, 12(2s), 1101-1109.

Noor, A. M.(2009). 'A Shariah Compliance Review on Investment Linked Takaful in Malaysia'.Islamic Economic Studies, 17(1).

Odierno, H. S.(2012).Invesments in Takaful. World Bank Publications, Washington.

Olorogun, L. A. (2015). A proposed contribution model for general Islamic insurance industry. International Journal of Islamic and Middle Eastern Finance and Management, 8(1).https://doi.org/10.1108/IMEFM-04-20140032.

Parveen, T., Razali, S. S., \& Salleh, M. C. M. (2019). Investment-Linked Takaful Plan Patronage: Evidence from Malaysia. Global Review of Islamic Economics and Business, 7(1), 041048.https://doi.org/10.14421/grieb.2019.071-04.

Rahmanto, D. N. A., Fasa, M. I., \& Rijal, K. (2020). Source of funds and Islamic insurance growth: investment returns as a mediation. Al-Uqud: Journal of Islamic Economics, 4(1).https://doi.org/10.26740/al-uqud.v4n1.p104-114

Remli, N., \& Rosman, M. M. R. (2018). Firms' characteristics: a preliminary study of family takaful demand in Malaysia. International Journal of Accounting, Finance and Business (IJAFB), 3(14), $01-14$.

Salleh, M. C. M., \& Laksana, N. N. M. (2018). Awareness of flood victims in the east-coast region of Malaysia towards the takaful flood policy: a crosstabulation analysis based on demographic variables.Management \& Accounting Review, 17(1), 63-78.http://dx.doi.org/10.24191/mar.v17i1.756

Shahid, I. (2020). Macroeconomic essence of takaful: exploring the significance and impact of takaful in macroeconomic context. Journal of Emerging Economies and Islamic Research, 6(1), 26-31. https://doi.org/10.24191/jeeir.v6i1.8771. 
Singh, R.(2013). 'Takaful Companies Plan to Dispose General Biz', The Sun.

Soualhi, Y., \& Al Shammari, A. A. R. (2015). Indicators of takaful awareness among Kuwaitis. Journal of Islamic Banking and Finance, 3(2). https://doi.org/10.15640/jibf.v3n2a8

Tolefat, A. K.(2009). 'Investment Portfolios of Takaful Undertakings'. In Archer, S., Karim, R. A. A., \& Nienhaus, V. (Eds.),Takaful Islamic Insurance(pp. 217-238).John Wiley \& Sons (Asia) Pte. Ltd.

Tolefat, A. K.,\& Asutay, M.(2013).Takaful Investment Portfolios a Study of the Composition of Takaful Funds in the GCC and Malaysia. John Wiley \& Sons.

Wahab, M. Z. H., \& Tajuddin, A. M. (2020). The roles of health awareness and knowledge in medical takaful purchase intention. International Journal of Banking and Finance, 14, 95-116.

Zakaria, M. Z., Salleh, A. Z., Hasbullah, M., Ismail, A. M., \& Ab Jalil, M. A. (2019). Exploring waqf-based takaful fund as financial aid for the B40 group in Malaysia. Al-Shajarah: Journal of the International Institute of Islamic Thought and Civilization (ISTAC), 149-167. 